\title{
A preliminary study to conceptualize professionalism in the field of veterinary medicine*
}

\section{Veteriner hekimliğinde profesyonalizmi kaviramsallaştırmaya yo̊nelilk bir ön çalışma}

Aytaç Ünsal ${ }^{a}$, Raziye Tamay Başağaç Gül ${ }^{a}$, Nigar Yerlikayaa

Introduction: Although the concept of professionalism is widely used in all over the world, there is no clear definition that describes exactly what it is. This is thought to result from different meanings which are attributed to the concept of profession. The number of researches and publications on medical professionalism has increased rapidly in recent years. In this sources some definitions reveal a detailed list of keywords. Compared with medicine, veterinary medicine has still got limited studies on this subject. This research was carried out to determine how veterinarians conceptualize professionalism in the field of veterinary medicine.

Methods: This qualitative study was designed as an Interpretative Phenomenological Analysis (IPA). The sample was consisted of veterinarians who have carried out their duties at the Veterinary School of Ankara University. The sampling strategy was purposive sampling. Data were collected via semi-structured interviews then content analysis was applied. During this process, internal and external consistencies were checked with an expert's help. As a result of the analysis the meaning units were created and classified. Results were shown in the tables, interpreted and then discussed.

Results: In this study it is found that veterinary and human medicines have many common terms for conceptualization of professionalism. Veterinary professionalism were conceptualized with similar approaches by experienced and inexperienced veterinarians. Ethics and moral values were expressed primarily and together in participant's approaches to this concept. The definition of good veterinarians is generally consistent with the definition of veterinary professionalism.

Discussion And Conclusion: Compared with medicine, veterinary medicine has still got limited studies about professionalizm. This research shows that veterinarians conceptialize professionalism by using some terms and explanations related to some values and desired behaviors of which many of them are also used for conceptialize medical professionalism. Among them ethics-moral values have been given priority. These values and behaviours are also refered for the definition of good veterinarian. There is no doubt that the meaning units; which were given in this study are not enough for the definition of veterinary professionalism. However, these units offer a good starting point for similar works to be done in the near future.

Keywords: Ethical-moral values, Interpretative Phenomenological Analysis (IPA), professional experience, veterinary professionalism

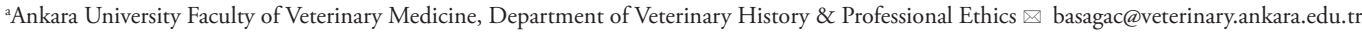
*This article was developed on the basis of the presentation "The Good The Bad and The Ugly: A Pilot Study From Turkey", presented at the 18th Annual Conference and Methodology Seminar, Berlin, 13th - 14th November 2015.

Gönderim Tarihi: 15.07.2016 • Kabul Tarihi: 26.11.2016
} 
Giriş ve Amaç: Profesyonalizm kavramı tüm dünyada yaygın olarak kullanılsa da, ne olduğuna dair açık bir tanım bulunmamaktadır. Bu durumun meslek kavramına yüklenen fark-

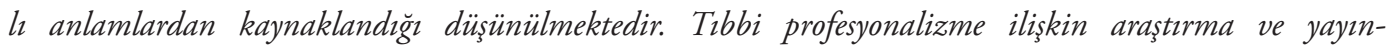
ların sayısında son yıllarda hızlı bir artı̧ yaşanmakta; bu kaynaklardaki bazı tanımlar ayrıntılı bir anahtar kelime listesini ortaya koymaktadır. Veteriner hekimliğinde bu konudaki çalısmalar insan hekimliği ile karşılaştırıldığında hala sınırlı sayıda kalmıştır. Bu araştırma, veteriner hekimliği alanında veteriner hekimlerin profesyonalizmi nasıl kavramsallaştırdıklarını tanımlamak amacıyla gerçekleştirilmiştir. Yöntem ve Gereçler: Bu nitel araştırma Yorumlayıcı Fenomenolojik Analiz olarak tasarlanmıstır. Örneklemde, Ankara Üniversitesi Veteriner Fakültesinde çalışan veteriner hekimler yer almıştır. Örneklem stratejisi olarak amaçlı örnekleme yöntemi seçilmiştir. Veriler yarı yapılandırılmıs görüşmeler aracılĭ̆ıyla toplanmıs, daha sonra içerik analizi uygulanmıştır. Bu işlem sırasında bir uzman yardımıyla iç ve diş tutarlıklar kontrol edilmiştir. Analiz sonucunda anlam üniteleri oluşturulmuş ve sınıflandırılmıştır. Bulgular tablolar halinde gösterilmiş ve yorumlanarak tartışılmıştır. Bulgular: Bu çalısmada, veteriner hekimliği ve insan hekimliğinde profesyonalizm kavramın tanımlamak için kullanılan birçok ortak terim olduğu saptanmıştır. Veteriner hekimliğinde profesyonalizm deneyimli ve deneyimsiz veteriner hekimler tarafindan benzer yaklaşımlarla kavramsallaştırılmıştır. Katılımcıların bu kavrama yaklaşımlarında etik ve ablaki değerler öncelikli olarak ve birlikte ifade edilmiştir. İyi veteriner hekim tanımının genel olarak veteriner hekimliğinde profesyonalizm tanımıyla uyumlu olduğu gözlenmiştir. Tartışma ve Sonuç: Insan hekimliği ile karşılaştırıldı̆̆ında, veteriner hekimliğinde profesyonalizm kavramı ile ilgili sınırlı sayıda çalışma mevcuttur. Bu çalışma, veteriner hekimlerin profesyonalizmi; çoğunlukla tıbbi profesyonalizmi tanımlamak için kullanılan birtakım değerler ve beklenen davranışlarla ilgili bazı terim ve açıklamalar kullanarak kavramsallaştırdıkların göstermiştir. Bunların arasında etik ve ablaki değerlere öncelik verilmiştir. Bu değerlere ve davranışlara iyi veteriner hekimin tanımlanmasında da atıfta bulunulmustur. Kuşkusuz, bu çalı̧̧mada verilen anlam ünitelerini veteriner hekimliğinde profesyonalizmi tanımlamak için yeterli değildir. Ancak bu ünitelerin, gelecekte yapılacak benzer çalışmalar için iyi bir başlangıç noktası sundukları da kabul edilmelidir.

Anabtar Kelimeler: Etik-ahlaki değgerler, mesleki deneyim, veteriner hekimliğinde profesyonalizm, Yorumlayıcı Fenomenolojik Analiz

\section{INTRODUCTION}

Although the concept of "professionalism" is widely used all over the world today, there is no clear definition that describes exactly what it is. This is thought to result from different meanings which are attributed to the concept of profession, the origin of professionalism.

In Oxford English Dictionary (1), profession is "an occupation in which a professed knowledge of some subject, field, or science is applied; a vocation or career, especially one that involves prolonged training and a formal qualification" and it is emphasized that in the past, this was generally applied to divinity, law and medicine. Professional is described as "relating to or belonging to a profession" (1). In today's languages, this word has occasionally used as synonymous with occupation. Moline (2) argues that all occupations are trying to become professionalised. He describes the existence of a desire to move away from the amateur status and be "honoured" with the label of professional. Thistlethwaite and Spencer (3) discuss other understanding of the word professional - as the opposite of amateur, therefore possessing superior skills which are worth paying 
for such as in sport or music, and also when it is used to describe a job which is carried out "with calculated efficiency without fuss or emotion".

Professionalism has become one of the most common concepts in medical education over the past 20 years in the world (4-11). While it was conceptually discussed in the past, it has become a field of competence in graduate and postgraduate medical curricula today. The number of researches and publications on medical professionalism has also increased rapidly in recent years. According to medical literature (5), individuals and institutions generally give short and precise definitions of professionalism; include three or four features to define medical professionalism. But in some resources $(7-10,12)$, some definations reveal a detailed list of keywords such as altruism (absence of self-interest), accountability, integrity, excellence (commitment to life-long learning), service, respect for others; additional humanistic qualities; honesty, scientific knowledge, duty, communication skills, personal values, ethical behaviour, moral values, responsibility to profession, decision making, manners, empathy, confidence and knowing limits, efficiency, trustworthy, collaboration, technical competency.

Compared with medicine, veterinary medicine has still got limited studies (12-20) on this subject, no true definition of veterinary professionalism exists and the teaching of the values and behaviors expected of veterinary professionals may not be explicit.

As a preliminary study, this qualitative research was carried out to determine how veterinarians conceptualize professionalism in the field of veterinary medicine with the sample of veterinarians from the Veterinary School of Ankara University.

\section{MATERIAL-METHODS}

\section{Design of the study}

At the beginning of this study, related literature was detailly reviewed and the subject was carefully consulted with the experts from the field of social sciences. As a result, this study was designed as an Interpretative Phenomenological Analysis (IPA), which has been developed as a distinctive approach to conducting qualitative researches.

\section{Sample}

The sample was consisted of veterinarians who have carried out their duties at the Veterinary School of Ankara University. The sampling strategy was purposive sampling since it ensures a homogenous sample of participants with common characteristics and experiences (21).

\section{Data collection}

In order to collect data, a guide for semi-structured interviews, which deeply expose experiences and provide researchers both flexibility and ease of interaction, were developed. At the first step, a draft form - focused on sociodemographic characteristics, professional experiences, conceptualization of professionalism and definations of "good" and "bad" veterinarian respectively - prepared with the help of the experts. Six veterinarians were interviewed in order to test whether the form work or not during interviews. In accordance with the views and critics the form had its final content.

At the beginning of the interviews, the aim and the method of this study was clearly explained to the participants, in addition they were informed that the interviews were recorded and the responses would be 
kept confidential. Their written permissions were taken. Then the interviews were begun. The average time for each was 30 minutes. Interviews continued as long as data diversity persisted. Thus 35 interviews were realized.

\section{Limitations}

For this research a number of sociodemographic features such as age, gender, service field, qualification of professional experience, professional title were also collected. But both researchers were not familiar with the method of this study and there were not enough publications to guide. So for this preliminary study, the hypothesis was formed as "professionalism is positively affected by professional experience". That is why only professional experience was considered in the conceptualization of professionalism and other features were excluded for further studies. In addition, as the aim of this research was to determine the meaning units, which were used by participant veterinarians during the conceptualisation of professionalism, discussions and comments were carried out in general framework and meaning units were not discussed separately.

\section{Data analysis}

Data was applied content analysis. For this aim each interview was electronically transcripted and coded. Regarding related literature and similar IPA studies (5,21-23), each author separately read the transcript of the first interview as a whole then completed a line-by-line analysis of the transcript to code for the participant's experiences based on the research questions. By this way, each author separately organized coded texts into inductive themes. After this process, each coding scheme was compared to discuss similarities and differences as Patton (24) informed. Discussions continued until an agreed set of themes and supporting quotes were identified. As a result, a consensus chart of codes (a thematic code list) was created. During this process, internal and external consistencies were checked with an expert's help. This prosedure was applied for all transcripts. Then the "meaning units" (key words/key sentences) were created and classified according to junior and senior veterinarians' respeonses and results were shown in the tables, interpreted and then discussed. Local legislation (Law Nr: 6343, Official Newspaper Nr: 8661, $18^{\text {th }}$ March 1954) was taken into consideration for the definition of junior and senior veterinarians. Accordingly, veterinarians with at least 15 years of professional experience and for this reason have right to be elected to the Higher Honour Council of the Turkish Veterinary Medical Association were accepted as "senior". And those with less experience than 15 years were called as "junior".

\section{Reliability and Validity}

The sample of this research had been enriched as much as possible with the participation of individuals in different views. During the preperation process of the form for semi-structured interviews, related literature was detailly inspected and the process was consulted with supported by the experts from different fields. The consistency between the research question, purpose and data collection tools was constantly taken into account. It had been constantly examined whether the meaning units (key words and key sentences) were consistent with each other and with the thematic codes in the list. Records and transcriptions have been kept in the archive.

\section{RESULTS}

The researchers of the study interviewed totally 35 veterinarians. Thirteen of all participants had less than 10 years experience, 7 had 10-20 years, 7 had 20-30 years, 5 had 30-40 years and 3 had over 40 years relevant 
work experience. In general, 18 of them had less than 15 years experience (junior veterinarians) and 17 had more than 15 years experience (senior veterinarians). The most inexperienced participant was VET11 with two years experience and the most experienced participant was VET2 with 44 years experience in the profession (Table 1).

Table 1: Personal characteristics of participants

\begin{tabular}{|c|c|c|c|c|c|c|c|}
\hline \multicolumn{7}{|c|}{ Professional Experiences } \\
\hline \multicolumn{2}{|c|}{ Less than 10 years } & \multicolumn{2}{|c|}{ 10 to 20 years } & \multicolumn{2}{c|}{ 21 to 30 years } & \multicolumn{2}{c|}{ 31 and more years } \\
\hline $\begin{array}{c}\text { Codes of } \\
\text { Veterinarians }\end{array}$ & Years & $\begin{array}{c}\text { Codes of } \\
\text { Veterinarians }\end{array}$ & Years & $\begin{array}{c}\text { Codes of } \\
\text { Veterinarians }\end{array}$ & Years & $\begin{array}{c}\text { Codes of } \\
\text { Veterinarians }\end{array}$ & Years \\
\hline VET 3 & 8 & & & & & & \\
VET 5 & 7 & & & & & & \\
VET 6 & 6 & VET 4 & 13 & VET 16 & 28 & VET 1 & 42 \\
VET 7 & 8 & VET 12 & 14 & VET 19 & 24 & VET 2 & 44 \\
VET 9 & 6 & VET 13 & 12 & VET 20 & 26 & VET 8 & 39 \\
VET 10 & 8 & VET 14 & 16 & VET 21 & 22 & VET 15 & 40 \\
VET 11 & 2 & VET 25 & 12 & VET 23 & 26 & VET 17 & 40 \\
VET 22 & 3 & VET 26 & 10 & VET 30 & 23 & VET 18 & 42 \\
VET 24 & 4 & VET 33 & 19 & VET 32 & 27 & VET 31 & 33 \\
VET 27 & 6 & & & & & VET 34 & 37 \\
VET 28 & 7 & & & & & & \\
VET 29 & 3 & & & & & & \\
VET 35 & 5 & & & & & & \\
\hline
\end{tabular}

Table 2 shows the meaning units, which were created by taking into account the participants' definitions about professionalism. As it can be seen in the Table, the majority of both junior and senior veterinarians' definitions (total number: $\mathrm{n}_{\mathrm{t}}=14$ ) were related to the meaning unit with the title "ethical-moral values".

The equal number of junior and senior participants' definitions were related to the meaning units with the titles "professional responsibilities" (number of juniors: $\mathrm{n}_{\mathrm{j}}=5$; number of seniors: $\left.\mathrm{n}_{\mathrm{s}}=5\right)$ ) "specialisation" $\left(\mathrm{n}_{\mathrm{j}}=4\right.$, $\left.\mathrm{n}_{\mathrm{s}}=4\right)$, "competency" $\left(\mathrm{n}_{\mathrm{j}}=1, \mathrm{n}_{\mathrm{s}}=1\right)$, "respectful to animals and animal rights" $\left(\mathrm{n}_{\mathrm{j}}=1, \mathrm{n}_{\mathrm{s}}=1\right)$ and "communication" $\left(\mathrm{n}_{\mathrm{j}}=1, \mathrm{n}_{\mathrm{s}}=1\right)$.

Apart from common definitions, only one junior vet's (VET6) defination was related to "objectivity" and two senior vets' (VET1 and VET20) definitions were related to "respectful to animal owners" and "free thinking". 
Table 2: Definition of veterinary professionalism

\begin{tabular}{|c|c|c|c|}
\hline Meaning Units & $\begin{array}{c}\text { Junior Vets } \\
\text { (Experiences } \leq 15 \text { years) }\end{array}$ & $\begin{array}{c}\text { Senior Vets } \\
\text { (Experiences } \geq 15 \text { years) }\end{array}$ & $\begin{array}{c}\text { Total } \\
(\mathbf{n})\end{array}$ \\
\hline ethical - moral values & $\begin{array}{c}\mathbf{n = 8} \\
(\text { VET 3-5-7-10-1 1-25-26-29) }\end{array}$ & $\begin{array}{c}\mathbf{n}=\mathbf{6} \\
(\text { VET 2-15-16-18-23-31) }\end{array}$ & 14 \\
\hline professional responsibilities & $\begin{array}{c}\mathbf{n}=\mathbf{5} \\
(\text { VET 4-5-7-10-25) }\end{array}$ & $\begin{array}{c}\mathbf{n}=\mathbf{5} \\
(\text { VET 2-16-21-23-34) }\end{array}$ & 10 \\
\hline professional improvement & $\begin{array}{c}\mathbf{n}=\mathbf{5} \\
(\text { VET } 4-11-27-28-29)\end{array}$ & $\begin{array}{c}\mathbf{n}=\mathbf{4} \\
(\text { VET 14-16-32-33) }\end{array}$ & 9 \\
\hline $\begin{array}{l}\text { qualification and technical } \\
\text { skills }\end{array}$ & $\begin{array}{c}\mathbf{n}=\mathbf{5} \\
(\text { VET 4-6-22-26-35) }\end{array}$ & $\begin{array}{c}\mathbf{n}=\mathbf{3} \\
(\text { VET 8-20-23) }\end{array}$ & 8 \\
\hline specialisation & $\begin{array}{c}\mathbf{n}=\mathbf{4} \\
(\text { VET 9-24-27-12) }\end{array}$ & $\begin{array}{c}\mathbf{n}=\mathbf{4} \\
(\text { VET 14-17-30-32) }\end{array}$ & 8 \\
\hline scientific attitude & $\begin{array}{c}\mathbf{n}=\mathbf{2} \\
(\text { VET 3-10) } \\
\end{array}$ & $\begin{array}{c}\mathbf{n}=\mathbf{4} \\
(\text { VET } 1-18-19-21) \\
\end{array}$ & 6 \\
\hline competency & $\begin{array}{c}\mathbf{n = 1} \\
(\text { VET 13) }\end{array}$ & $\begin{array}{c}\mathbf{n}=\mathbf{1} \\
(\operatorname{VET} 32)\end{array}$ & 2 \\
\hline $\begin{array}{l}\text { respectful to animals and ani- } \\
\text { mal rights }\end{array}$ & $\begin{array}{c}\mathbf{n}=\mathbf{1} \\
(\operatorname{VET} 25)\end{array}$ & $\begin{array}{c}\mathbf{n}=\mathbf{1} \\
(\mathrm{VET} 18)\end{array}$ & 2 \\
\hline communication & $\begin{array}{c}\mathbf{n = 1} \\
(\text { VET 29) }\end{array}$ & $\begin{array}{c}\mathbf{n}=\mathbf{1} \\
(\mathrm{VET} 8)\end{array}$ & 2 \\
\hline objectivity & $\begin{array}{c}\mathbf{n}=\mathbf{1} \\
(\mathrm{VET} 6)\end{array}$ & - & 1 \\
\hline respectful to animal owners & - & $\begin{array}{c}\mathbf{n}=\mathbf{1} \\
(\operatorname{VET} 20)\end{array}$ & 1 \\
\hline free thinking & - & $\begin{array}{c}\mathbf{n = 1} \\
(\operatorname{VET} 1)\end{array}$ & 1 \\
\hline
\end{tabular}

The meaning units, created by taking into account the participants' answers to the question about "the most important features of veterinary professionalism" are given in Table 3. As can be seen in the Table, the responses of 10 participants, junior and senior, were about "ethical-moral values". As for other meaning units, it was seen that the responses related to "qualification and competency" $\left(\mathrm{n}_{\mathrm{t}}=7\right)$ and "scientific attitude" $\left(\mathrm{n}_{\mathrm{t}}=6\right)$ were more privileged than others. While the responses related to the meaning unit "respect for the profession" $\left(\mathrm{n}_{\mathrm{j}}=3\right)$, "professional knowledge and skills" (VET11 and VET27) and "education"(VET13) were stated by only junior veterinarians; the responses related to the meaning units "respects for living creatures", "get the fruits of labor" and "experience" were stated by only seniors (VET20, VET2, and VET23).

VET30 misunderstood the question in this part, and answered as if the question was "what are the fields of veterinary medicine". During interviews, the responses were not manuplated by researchers. VET30 was not insisted on changing his response; so his answer was not evaluated in this section. 
Table 3: The most important features of veterinary professionalism

\begin{tabular}{|c|c|c|c|}
\hline Meaning Units & $\begin{array}{c}\text { Junior Vets } \\
\text { (Experiences } \leq 15 \text { years) }\end{array}$ & $\begin{array}{c}\text { Senior Vets } \\
\text { (Experiences } \geq 15 \text { years) }\end{array}$ & $\begin{array}{c}\text { Total } \\
(\mathbf{n})\end{array}$ \\
\hline ethical - moral values & $\begin{array}{c}\mathbf{n}=\mathbf{5} \\
(\text { VET 3-7-12-25-29) }\end{array}$ & $\begin{array}{c}\mathbf{n}=\mathbf{5} \\
(\text { VET 14-15-16-17-32) }\end{array}$ & 10 \\
\hline qualification and competency & $\begin{array}{c}\mathbf{n}=\mathbf{4} \\
(\text { VET } 4-9-24-26)\end{array}$ & $\begin{array}{c}\mathbf{n}=\mathbf{3} \\
(\text { VET 8-19-31) }\end{array}$ & 7 \\
\hline scientific attitude & $\begin{array}{c}\mathbf{n}=\mathbf{2} \\
(\operatorname{VET} 28-35)\end{array}$ & $\begin{array}{c}\mathbf{n}=\mathbf{4} \\
(\text { VET 18-21-33-34) }\end{array}$ & 6 \\
\hline respect for the profession & $\begin{array}{c}\mathbf{n}=\mathbf{3} \\
(\text { VET 5-10-22) }\end{array}$ & - & 3 \\
\hline objectivity & $\begin{array}{c}\mathbf{n = 1} \\
(\text { VET 6) }\end{array}$ & $\begin{array}{c}\mathbf{n = 1} \\
(\mathrm{VET} 1)\end{array}$ & 2 \\
\hline professional knowledge and skills & $\begin{array}{c}\mathbf{n}=\mathbf{2} \\
(\operatorname{VET} 11-27)\end{array}$ & - & 2 \\
\hline education & $\begin{array}{c}\mathbf{n = 1} \\
(\operatorname{VET} 13)\end{array}$ & - & 1 \\
\hline respect for living creatures & - & $\begin{array}{c}\mathbf{n}=\mathbf{1} \\
(\operatorname{VET} 20)\end{array}$ & 1 \\
\hline get the fruits of labor & - & $\begin{array}{c}\mathbf{n = 1} \\
(\text { VET 2) }\end{array}$ & 1 \\
\hline
\end{tabular}

Table 4 and Table 5 show the meaning units which were created by taking into account the participants' definitions about "good veterinarian" and "bad veterinarian" respectively. As it is seen in Table 4; according to majorities; a good veterinarian "is faithful to professional and ethical principles" $\left(\mathrm{n}_{\mathrm{t}}=16\right)$ and "maintains professional improvement" $\left(\mathrm{n}_{\mathrm{t}}=14\right)$. Amongst juniors responses, there were no definitions about respectfulness, taking responsibility and involving in professional organisations, and amongst senior responses there were no definitions about reliability and honesty, altruism, communication skills and non-discrimination. 
Table 4: Definition of a "good" veterinarian

\begin{tabular}{|c|c|c|c|}
\hline Meaning Units & $\begin{array}{c}\text { Junior Vets } \\
\text { (Experiences } \leq 15 \text { years) }\end{array}$ & $\begin{array}{c}\text { Senior Vets } \\
\text { (Experiences } \geq 15 \text { years) }\end{array}$ & $\begin{array}{c}\text { Total } \\
(\mathbf{n})\end{array}$ \\
\hline $\begin{array}{l}\text { is faithful to professional } \\
\text { and ethical principles }\end{array}$ & $\begin{array}{c}\mathbf{n}=\mathbf{1 0} \\
(\text { VET 3-6-7-10-12-13-25-26-28-35) }\end{array}$ & $\begin{array}{c}\mathbf{n}=\mathbf{6} \\
(\text { VET 14-15-16-21-31-34) }\end{array}$ & 16 \\
\hline $\begin{array}{l}\text { maintains professional } \\
\text { improvement }\end{array}$ & $\begin{array}{c}\mathbf{n}=\mathbf{8} \\
(\text { VET 3-5-9-12-13-24-25-26) }\end{array}$ & $\begin{array}{c}\mathbf{n}=\mathbf{6} \\
(\text { VET 17-19-23-30-33-34) }\end{array}$ & 14 \\
\hline $\begin{array}{l}\text { has qualifications and } \\
\text { competencies }\end{array}$ & $\begin{array}{c}\mathbf{n}=\mathbf{2} \\
(\operatorname{VET~4-27)}\end{array}$ & $\begin{array}{c}\mathbf{n}=\mathbf{6} \\
(\text { VET 1-14-18-20-23-30) }\end{array}$ & 8 \\
\hline $\begin{array}{l}\text { gives importance to pro- } \\
\text { fessional interests }\end{array}$ & $\begin{array}{c}\mathbf{n}=\mathbf{3} \\
(\text { VET } 7-11-26)\end{array}$ & $\begin{array}{c}\mathbf{n}=\mathbf{1} \\
(\text { VET 16) }\end{array}$ & 4 \\
\hline is specialist & $\begin{array}{c}\mathbf{n}=\mathbf{2} \\
(\mathrm{VET} 24-28)\end{array}$ & $\begin{array}{c}\mathbf{n}=\mathbf{2} \\
(\text { VET 31-32) }\end{array}$ & 4 \\
\hline is non-greed & $\begin{array}{c}\mathbf{n}=\mathbf{1} \\
(\text { VET 25) }\end{array}$ & $\begin{array}{c}\mathbf{n}=\mathbf{2} \\
(\text { VET } 8-31)\end{array}$ & 3 \\
\hline is animal lover & $\begin{array}{c}\mathbf{n}=\mathbf{1} \\
(\operatorname{VET} 13)\end{array}$ & $\begin{array}{c}\mathbf{n}=\mathbf{2} \\
(\text { VET } 15-20)\end{array}$ & 3 \\
\hline is utilitarist & $\begin{array}{c}\mathbf{n}=\mathbf{1} \\
(\text { VET 3) } \\
\end{array}$ & $\begin{array}{c}\mathbf{n}=\mathbf{1} \\
(\mathrm{VET} 8) \\
\end{array}$ & 2 \\
\hline is reliable and honest & $\begin{array}{c}\mathbf{n}=\mathbf{2} \\
(\mathrm{VET} 25-29) \\
\end{array}$ & - & 2 \\
\hline is altruistic & $\begin{array}{c}\mathbf{n}=\mathbf{1} \\
(\text { VET 5) }\end{array}$ & - & 1 \\
\hline is respectful & - & $\begin{array}{c}\mathbf{n}=\mathbf{1} \\
(\operatorname{VET} 18)\end{array}$ & 1 \\
\hline takes responsibility & - & $\begin{array}{c}\mathbf{n}=\mathbf{1} \\
(\text { VET 2) }\end{array}$ & 1 \\
\hline has communication skills & $\begin{array}{c}\mathbf{n}=\mathbf{1} \\
(\operatorname{VET} 28)\end{array}$ & - & 1 \\
\hline does not discriminate & $\begin{array}{c}\mathbf{n}=\mathbf{1} \\
(\mathrm{VET} 22)\end{array}$ & - & 1 \\
\hline $\begin{array}{l}\text { is involved in professional } \\
\text { organizations }\end{array}$ & - & $\begin{array}{c}\mathbf{n}=\mathbf{1} \\
(\operatorname{VET} 34)\end{array}$ & 1 \\
\hline
\end{tabular}

And as it is seen in Table 5; according to majority of junior veterinarians a bad veterinarian "is a person who paid attention to fees" ( $\left.\mathrm{n}_{\mathrm{j}}=9\right)$; and according to majority of senior veterinarians a bad veterinarian "is a person who was not competent in scientific, technical and social aspects" $\left(\mathrm{n}_{\mathrm{s}}=9\right)$. It is also noticed that the same number of junior and senior veterinarians agreed that a bad veterinarian "is a person who acted unethically" $\left(\mathrm{n}_{\mathrm{j}}=6\right.$, $\left.\mathrm{n}_{\mathrm{s}}=5\right)$. Apart from common definitions; while "disrespectfulness to nature" was expressed by only one senior veterinarian (VET20), "discrimination", "uncompassion" and "biased" were stated by only three different junior veterinarians (VET22, VET7 and VET6). 
Table 5: Definition of a "bad" veterinarian

\begin{tabular}{|c|c|c|c|}
\hline Meaning Units & $\begin{array}{c}\text { Junior Vets } \\
\text { (Experiences } \leq 15 \text { years) }\end{array}$ & $\begin{array}{c}\text { Senior Vets } \\
\text { (Experiences } \geq 15 \text { years) }\end{array}$ & $\begin{array}{c}\text { Total } \\
(\mathbf{n})\end{array}$ \\
\hline pays attention to fees & $\begin{array}{c}\mathbf{n}=\mathbf{9} \\
(\text { VET 3-4-7-9-11-12-25-27-29) }\end{array}$ & $\begin{array}{c}\mathbf{n}=\mathbf{5} \\
\text { (VET 2-15-16-18-32) }\end{array}$ & 14 \\
\hline $\begin{array}{l}\text { is not competent in } \\
\text { scientific, technical and } \\
\text { social aspects }\end{array}$ & $\begin{array}{c}\mathbf{n}=\mathbf{3} \\
(\text { VET 5-10-26) }\end{array}$ & $\begin{array}{c}\mathbf{n}=\mathbf{9} \\
(\text { VET 8-14-18-20-23-30-31-33-34) }\end{array}$ & 12 \\
\hline acts unethically & $\begin{array}{c}\mathbf{n}=\mathbf{6} \\
\text { (VET 5-12-13-24-26-35) }\end{array}$ & $\begin{array}{c}\mathbf{n}=\mathbf{5} \\
(\text { VET 14-17-19-31-34) }\end{array}$ & 11 \\
\hline $\begin{array}{l}\text { abuses his knowledge } \\
\text { and skills }\end{array}$ & $\begin{array}{c}\mathbf{n}=\mathbf{5} \\
(\text { VET 6-7-10-26-29) }\end{array}$ & $\begin{array}{c}\mathbf{n}=\mathbf{1} \\
(\text { VET 21) } \\
\end{array}$ & 6 \\
\hline $\begin{array}{l}\text { harms to professional } \\
\text { dignity }\end{array}$ & $\begin{array}{c}\mathbf{n}=\mathbf{2} \\
(\text { VET 9-24) }\end{array}$ & $\begin{array}{c}\mathbf{n}=\mathbf{3} \\
(\text { VET 8-18-19) }\end{array}$ & 5 \\
\hline is smarty-pants & $\begin{array}{c}\mathbf{n = 1} \\
(\text { VET 27) }\end{array}$ & $\begin{array}{c}\mathbf{n}=\mathbf{1} \\
(\text { VET1) }\end{array}$ & 2 \\
\hline is disrespectful to nature & - & $\begin{array}{c}\mathbf{n}=\mathbf{1} \\
(\text { VET 20) }\end{array}$ & 1 \\
\hline does discriminate & $\begin{array}{c}\mathbf{n = 1} \\
\text { (VET 22) }\end{array}$ & 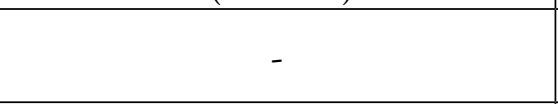 & 1 \\
\hline is uncompassion & $\begin{array}{c}\mathbf{n = 1} \\
(\text { VET 7) }\end{array}$ & - & 1 \\
\hline is biased & $\begin{array}{c}\mathbf{n = 1} \\
(\text { VET 6) }\end{array}$ & - & 1 \\
\hline
\end{tabular}

\section{DISCUSSION AND CONCLUSION}

Mıdık and Batı (4) informed that Castellani and Hafferty have accepted medical professionalism as a new and complex system that is influenced by internal factors such as motivation, stress, character traits and external factors such as intitutional politics and practice envirement and they have defined seven professionalism dimensions. In their article these authors also emphasize that they could not access detailed forms similar to Castellani and Hafferty's research and they conceptualized professionalism in three dimensions with subtitles. Similar dimentions were not preferred by the researchers of this study. Because the emotional and service dimentions of veterinary medicine are very varied due to diversities of animal species; approaches to animals and social statues attributed to them. Nevertheless, this study displays many similarities between the meaning units of this study and the subtitles of dimentions in other studies $(4,5,9)$ related to medical professionalism. Regarding this situation, it can be said that veterinary medicine and human medicine have many common terms for conceptualize professionalism in their own fields. Therefore, human medical field helps us see beyond rules and behaviors as the foundation for professionalism in veterinary medicine as Mossop (15) underlined.

While the study was being planned, it was assumed that the professional experience would affect positively the conceptualization of professionalism. However, this research shown that there was general consistency between meaning units derived from conceptualizations of professionalism by junior and senior veterinarians. In other words professionalism were conceptualiezed with similar approaches by junior and senior veterinarians. So the result makes it difficult to establish a direct connection between professionalism and experience. At this point, it has also become obscure whether 15 years was a good choice to distinguish the experience or not. At the end of the study, the authors have agreed one more time that the quality of working period was more important than the quantity. However, they have been loyal to their records while preparing the tables. 
As it is shown in the results that majority (totally 14) of both junior and senior veterinarians' definitions of professionalism were related to the meaining unit "ethical-moral values". It is thought that participants may have considered the researchers' scientific field in responding to this question. On the other hand it may also be due to the increasing popularity of ethics in the field of veterinary medicine in recent years too (25). But there are no concrete evidences to confirm either of these two possibilities. In addition; it is also seen that ethics and moral values were expressed together in participant's approaches to veterinary professionalism. The distinction between ethics and morals is particularly important for ethicists and there are many academic publications (26-29) on this issue. But apart from ethicists, these two terms are generally used interchangeably by others in daily life.

Similar to ethics, communication skills has also taken place among the most popular topics of veterinary medicine today. In many publications $(7,8,12,30)$, it is constantly pointed out that communication skills is related to professional excellence. For this reason, it is thought to be strange that this skill was expressed by very few veterinarians.

It is shown in this article that 7 of 10 meaning units that the researchers used in Table 3 are same as, similar with or related to the 8 of 12 meaning units in Table 2 . Table 3, actually was prepared only for checking the internal consistency of this research and for pointing out to show this consistency, it was given here in the article.

Participants' definition of good veterinarians in this study is generally consistent with the definition of veterinary professionalism. In internet scans, it is seen that "good" and "professional" definitions are used together in many announcements and advertisement related to veterinarians and veterinary medicine.

While the most referenced title was "faithfulness to professional and ethical principles" in the definition of good veterinarian in this study; "unethically acts" were the third most preferred title in the definitian of bad veterinarian. According to most of the participants a bad veterinarian "is the person who pays attention to fees". Veterinarians of course are entitled to charge fees for their professional services and this subject has been detailly scrutinized in social media. Here, it is thought that this situation was expressed as a malicious advantage.

In conclusion, compared with medicine, veterinary medicine has still got limited studies about professionalizm. This research shows that veterinarians conceptialize professionalism by using some terms and explanations related to some values and desired behaviors of which many of them are also used for conceptialize medical professionalism. Among them ethics have been given priority. These values and behaviours are also refered for the definition of good veterinarian. There is no doubt that the meaning units; which were given in this study are not enough for the definition of veterinary professionalism. However, these units offer a good starting point for similar works to be done in the near future.

\section{REFERENCES}

1. No Title [Internet]. Oxford English Dictionary. [cited 2016 Mar 22]. Available from: http://www. oxforddictionaries.com/definition/english

2. Moline JN. Professionals and professions: a philosophical examination of an ideal. Soc Sci Med [Internet]. 1986 [cited 2016 Nov 27];22(5):501-8. Available from: http://www.ncbi.nlm.nih.gov/ pubmed/3704687

3. Thistlethwaite J, Spencer J (John A. Professionalism in medicine. Radcliffe; 2008. 230 p.

4. Mıdık Ö, Batı AH. The perception of medical professionalism: A conceptual framework. Marmara Med J [Internet]. 2014;27(2):121-8. Available from: https://www.scopus.com/inward/record.uri? eid=2s2.0-84924987715\&partnerID=40\&md5=16c0aa0e86e63b24f17340f91a54a0ac 
5. Mıdık Ö. Hekimlerin Tıbbi Profesyonalizmi Kavramsallaştırması ve Kavramsallaştırmayı Etkileyen Faktörlerin İncelenmesi: Samsun İl Merkezi Örneğinde Fenomenolojik Bir Çalışma. Ege Üniversitesi Sağlık Bilimleri Enstitüsü; 2012.

6. Stern DT, Papadakis M. The Developing Physician - Becoming a Professional. N Engl J Med. 2006;355(17):1794-9.

7. Kirk LM. Professionalism in medicine: definitions and considerations for teaching. Baylor Univ Med Cent Proc. 2007;20(1):13-6.

8. Arnold L. Assessing Professional Behavior : Yesterday, Today, and Tomorrow. 2002;502-15.

9. Al-Rubaish A. Professionalism today. J Fam Community Med [Internet]. 2010;17(1):1. Available from: http://www.e-jfcm.com/text.asp?2010/17/1/1/68781

10. Stobo J, Kohen J, Kimball H. Project professionalism [Internet]. Seventh pr. Vol. 60, American Board of Internal Medicine. Pennsylvania: American Board of Internal Medicine; 2001. 42 p. Available from: www.abim.org

11. Elçin M, Sayek İ. AMEE 2004’ün ardından. Hacettepe Tıp Derg. 2004;35:121-2.

12. Mossop L. Defining and teaching veterinary professionalism [Internet]. University of Nottingham; 2012. Available from: http://eprints.nottingham.ac.uk/12694/1/Fully_corrected_thesis_Liz_Mossop. $\mathrm{pdf}$

13. Armitage-Chan E, Whiting M. Teaching Professionalism: Using Role-Play Simulations to Generate Professionalism Learning Outcomes. J Vet Med Educ [Internet]. 2016 Nov [cited 2016 Nov 27];43(4):359-63. Available from: http://jvme.utpjournals.press/doi/10.3138/jvme.1115-179R

14. Armitage-Chan E, Maddison J, May SA. What is the veterinary professional identity? Preliminary findings from web-based continuing professional development in veterinary professionalism. Vet Rec [Internet]. 2016 Mar 26 [cited 2016 Nov 27];178(13):318-318. Available from: http://veterinaryrecord. bmj.com/lookup/doi/10.1136/vr.103471

15. Mossop LH. Is it Time to Define Veterinary Professionalism? J Vet Med Educ [Internet]. 2012 Mar [cited 2016 Nov 7];39(1):93-100. Available from: http://jvme.utpjournals.press/doi/10.3138/ jvme.0411.041R1

16. Mossop LH, Cobb K. Teaching and Assessing Veterinary Professionalism. J Vet Med Educ [Internet]. 2013 Sep [cited 2016 Nov 7];40(3):223-32. Available from: http://jvme.utpjournals.press/doi/10.3138/ jvme.0113-016R

17. Burns GA, Ruby KL, DeBowes RM, Seaman SJ, Brannan JK. Teaching Non-Technical (Professional) Competence in a Veterinary School Curriculum. J Vet Med Educ [Internet]. 2006 Jun [cited 2016 Nov 27];33(2):301-8. Available from: http://jvme.utpjournals.press/doi/10.3138/jvme.33.2.301

18. Armitage-Chan E. Assessing Professionalism: A Theoretical Framework for Defining Clinical Rotation Assessment Criteria. J Vet Med Educ [Internet]. 2016 Nov [cited 2016 Nov 27];43(4):364-71. Available from: http://jvme.utpjournals.press/doi/10.3138/jvme.1215-194R

19. Whiting M, Kinnison T, Mossop L. Teaching Tip: Developing an Intercollegiate Twitter Forum to Improve Student Exam Study and Digital Professionalism. J Vet Med Educ [Internet]. 2016 Jan [cited 2016 Nov 27];43(3):282-6. Available from: http://jvme.utpjournals.press/doi/10.3138/jvme.0715$114 \mathrm{R}$

20. Coe JB, Weijs CA, Muise A, Christofides E, Desmarais S. Teaching Veterinary Professionalism in the Face(book) of Change. J Vet Med Educ [Internet]. 2011 Dec [cited 2016 Nov 27];38(4):353-9. Available from: http://jvme.utpjournals.press/doi/10.3138/jvme.38.4.353 
21. Smith JA, M. O. Interpretative Phenomenological Analysis. Qual Psychol [Internet]. 2003;53-80. Available from: https://www.researchgate.net/file.PostFileLoader.html?id...

22. Smith, Jonathan A, Flowers P, Osborn M. Interpratative phenomenological analysis and the psychology of the health and illness. In: Yardley L, editor. Material Discourses of Health and Illness [Internet]. Taylor \& Francis e- Library; 2002. p. 256. Available from: https:// books.google.com.tr/books?id=7SaAj7F23vYC\&printsec=frontcover \&hl=tr\&source=gbs_ge_ summary_r\&cad $=0 \# \mathrm{v}=$ onepage\& $\mathrm{q} \& \mathrm{f}=$ false

23. Biggerstaff D, Thompson AR. Interpretative Phenomenological Analysis (IPA): A Qualitative Methodology ofChoice in Healthcare Research. Qual Res Psychol [Internet]. 2008 Sep 25 [cited 2016 Nov 27];5(3):214-24. Available from: http://www.tandfonline.com/doi/full/10.1080/14780880802314304

24. Patton MQ. Qualitative Research \&amp; Evaluation Methods. 3rd ed. USA: Sage Publications; 2002.

25. Tannenbaum J. Veterinary ethics: animal welfare, client relations, competition and collegiality. Second Edi. Don LAdig; 1995. 615 p.

26. Çobanoğlu N. Kuramsal ve Uygulamalı Tıp Etiği. Birinci Ba. Ankara: Eflatun Yayınevi; 2009. 352 p.

27. Pieper A. Etiğe Giriş. İkinci Bas. İstanbul: Ayrıntı Yayınları; 2012. 288 p.

28. Feldman F. Etik Nedir? Birinci Ba. İstanbul: Boğaziçi Üniversitesi Yayınevi; 2012. 368 p.

29. Özlem D. Etik Ahlak Felsefesi. Birinci Ba. Özkan K, editor. İstanbul: Notos Kitap Yayınevi; 2014. $200 \mathrm{p}$.

30. Kurtz S. Teaching and Learning Communication in Veterinary Medicine. J Vet Med Educ [Internet]. 2006 Mar [cited 2016 Nov 1];33(1):11-9. Available from: http://jvme.utpjournals.press/doi/10.3138/ jvme.33.1.11 